\title{
Perkembangan Politik Islam Kontemporer
}

\author{
Nursyamsu \\ STAI Darul Kamal NW Lombok Timur \\ nursyamsu.8485@gmail.com
}

\begin{abstract}
This article talks about Islam and politics are two interesting words to be discussed Islamic literatures. Many of the modern Islamic thinkers and modern neo, which tries to give an explanation of the relationship between Islam and politics.Religious and political discourse, particularly power management (religio-political power) has actually been growing since the middle of the century.In this article will discuss the contemporary Islamic thinkers view sperti Jamaluddin AlAfghani, Rashid Rhido, al-Maududi, Hasan Al-Bana etc.Besides, in this article see the political developments in the Islamic world, including the political history of Islam in Indonesia.

Keywords: Development of Contemporary Islamic Politic
\end{abstract}

\begin{abstract}
Abstrak: Artikel ini membahas tentang Islam dan politik dua kata yang menarik untuk diperbincangkan (discose) dalam khazanah Islam. Banyak dari para pemikir Islam modern dan neo modern,yang mencoba memberikan sebuah penjelasan hubungan antara Islam dan politik.Diskursus agama dan politik, khususnya pengelolaan kekuasaan (religio-political power) sebenarnya telah berkembang sejak abad tengah. Dalam artikel ini akan membahas mengenai pandangan pemikir Islam kontemporer sperti Jamaludin Al-Afghani, Rasyid Rhido, alMaududi, Hasan Albana dll. Disamping itu dalam artikel ini melihat perkembangan politik di dunia Islam termasuk sejarah politik Islam di Indonesia.
\end{abstract}

Kata kunci: Pemikiran, Politik, Islam kontemporer.

\section{Pendahuluan}

\section{Pengertian Politik Islam}

Politik merupakan cara dan upaya menangani masalah-masalah rakyat dengan seperangkat undang-undang untuk mewujudkan kemaslahatan dan mencegah hal-hal yang merugikan bagi kepentingan manusia.1 Dengan demikian Kata politik diambil dari bahasa Yunani dan atau latin politicosatau politicus yang berarti relating to citizen. Keduanya berasal dari kata polis yang berarti kota.

1 Fauzan, Islam dan Kemodernan Politik berbasis Pemuda, (Tangerang: Binamuda, 2008), 5. 
Kamus Besar Bahasa Indonesia mengartikan kata politik sebagai "segala urusan dan tindakan (kebajian, siasat, dan sebagainya) mengenai pemerintahan Negara atau terhadap Negara lain.”Juga dalam arti "kebajikan, cara bertindak (dalam menghadapi atau menangani satu masalah).”2

Dalam kamus bahasa Arab modern, kata politik biasanya diterjemahkan dengan kata siyasah.Kata ini terambil dari akar kata sasa-yasusu yang biasa diartikan mengemudi, mengendalikan mengatur, dan sebagainya. Dari akar kata yang sama ditemukan kata sus yang berarti penuh kuman, kutu, atau rusak.

Pengertian politik dalam fiqih Islam diantaranya menurut ulama Hanbaliyah, politik adalah sikap, perilaku dan kebijakan kemasyarakatan yang mendekatkan pada kemaslahatan, sekaligus menjauhkan dari kemafsadahan. Sedangkan Ulama Hanafiyah memberikan pengertian lain, yaitu mendorong kemaslahatan makhluk dengan memberikan petunjuk dan jalan yang menyelamatkan meraka di dunia dan akhirat.

Sedangkan menurut ulama Syafi'iyah mengatakan, politik harus sesuai dengan syari'at Islam, yaitu setiap upaya, sikap dan kebijakan untuk mencapai tujuan umum prinsip syari'at. 3Dalam Al-Qur'an tidak ditemukan kata yang berbentuk dari akar kata sasa-yasusu, namun ini bukan berarti Al-Quran tidak menguraikan sol politik. Sekian banyak ulama Al-Qur'an yang menyusun karya ilmiah dalam bidang politik dengan menggunakan Al-Qur'an dan sunah Nabi sebagai rujukan.Bahkan Ibnu Taimiyah (1263-1328) menamai salah satu karya ilmiahnya dengan As-Siyasah Asy-Syar'iyah (politik keagamaan).

Uraian Al-Qur'an tentang politik secara sepintas dapat ditemukan pada ayat-ayat yang berakar hukum. Kata ini pada mulanya berarti "menghalangi atau melarang dalam rangka perbaikan". Dari akar kata yang sama terbentuk kata hikmah yang pada mulanya berarti kendali. Makna ini sejalan dengan asal makna kata sasa-yasusu-sais-siyasat, yang berarti mengemudi, mengendalikan, pengendali, dan cara pengendalian.

${ }^{2}$ M. Quraish Shihab, Wawasan Al-Quran, (Mizan: Bandung, 1996), 416.

${ }^{3}$ KH. MA. Sahal Mahfudh, Nuansa FIQIH SOSIAL, LKiS, cet I 1994, Yogyakarta, 209-210. 
Politik adalah sesuatu dan agama adalah sesuatu yang lain. Dan sesungguhnya sistem pemerintahan dan pembentukan negara adalah atas dasar manfaat-manfaat amaliyah, bukan atas sesuatu yang lain.Berbagaikemajuan, di pergerakan-pergerakan sosial-politik. Dan muncul tantangan yang menyebabkan berbagai aturan normatif yang semula dianggap mapan kini mulai ditanyakan kembali. Salah satunya adalah hukum Islam dengan berbagai implikasi dan peran sosio-historisnya yang mendominasi pradaban Islam. Muhammad Abid Al-Jabiri, seorang sarjana kontemporer Arab menyatakan bahwa dalam kurun waktu yang sangat panjang kaum Muslim didominasi oleh peradaban fiqh. Maka pernyataan ini setidak-tidaknya sebagaimana $\mathrm{Schaht}^{4}$ menyinggung problematika kaum Muslimin, lebih dihadapkan kepada peran dan dinamika hukum Islam dari pada theologi.Baginya teologi tidak berperan secara aktif dalam membentuk peradaban Muslim.

Perihal tentang dinamika yang dimainkan kaum Muslim selanjutnya sebagaimana Fazlurrahman ${ }^{5}$ menyatakan bahwa pangkal pergolakan dalam pemikiran Islam adalah bermula dari politik kemudian membias pada persoalan theologi dan fiqh. Permasalahan yang bermula timbul adalah kesadaran kaum Muslimin terhadap persoalan politik belum menjadi wacana yang mandiri dan hampir-hampir belum menyentuh sama sekali terhadap orientasi politik secaranyata sebagai gerakan untuk menyatakan sebuah pembaharuan, maka artikulasi yangmudahditerima kaumMuslimsebagaiwahana perlanjutantersebut adalah fiqh. ${ }^{6}$

Politik bukanlah persoalan yang harus ditempatkan dalam wilayah fiqh ansich, akan tetapi kepentingan diskursus yang meletakkan ukuran rasio dengan aspek transenden dalam diskursus politik. Menariknya diskursus politik daritarikulur antara nilai transenden dengan kenyataan produk manusia sendiri yangharus

\footnotetext{
${ }^{4}$ LihatJoseph Schacht, introduction to Islamic Law,(Boston Clorendon Pres, 1967), 15.

${ }^{5}$ Lihat Fazlurrahman, Islam, alih bahasa ahsin Muhammad, (Bandung: Penerbit pustaka, 1986), 62. Muhammad Abu Zahrah,Tarikh al-Mazahib al-Islamiyyah, (Kairo: dan al-kutub al-Islamiyyah,t,t), 93.

${ }^{6}$ Untuk melihat hubungan antara siyasah yang didefinisikan sebagai politik dengan fiqhlihat Azyumardi Azra, "Siyasah, Syariah dan Historiografi, Refleksi sejarah Islam”, dalam Muhammad Wahyuni Nafis dkk.(ed). Kontektualisasi Ajaran Islam,(Jakarta: IPHI dan Paramadina, 1995, 452-463.
} 
ditentukan sendiri tanpa campur tangan Tuhan. Kondisi inilah yang telah mewarnai diskursus dalam pemikiran politik yang berbasis keagamaan.

Peradaban Islam tetapi juga pada peradaban-peradaban dunia yang lain. Selanjutnya untuk mengenali interaksi tentang Barat dan Islam dalam wacana yang saling mengadakan penetrasi sistem sosial, budaya dan sekaligus peradaban, maka wajah barat lebih bersifat agresif-hegemonic. Sementara disisi lain kaum Muslim lebih menampakkan perlawanan yang lebih bersifat radikal-transendental.

Alternatif perlawanan seperti ini dianggap sangat relevan dan strategis, karena lebih dekat dalam nuansake-ilahi-an, dimana penilaian ini harus diakui oleh kaum Muslim sebagai sumber yang bersifat mutlak.

Kaum Muslimin tidak mau didikte oleh barat dalam segala lini kehidupan kalau harus mengeliminasi pola tauhid yang bakuitu. ${ }^{7}$ Namun demikian pemandangan penolakan itu tidak serta merta didukung fakta yang aktual-rasional untuk mengakuinya sebagai keunggulan yang harus diterima dan justru harus ditolak dengan segala kekuatan yang ada bahwa hal tersebut sesungguhnya tidak Islami.

Dengan segala upaya kaum Muslim berusaha untuk menyelesaikan sendiri bahwa Islam telah menyediakan seperangkat tata-nilai yang lengkap bukan hanya pada masalah duniawi saja tetapi juga ukhrawi. Barangkali inilah yang menjadi platform perjuangan kaum Muslimin untuk menggali identitasnya sendiri tanpa harus berususah-payah mendapatkannya pada orang lain.

\section{Perkembangan Politik Islam}

Keberadaan negara tidak bisa dipisahkan dari agama, dalam batas tertentu harus terlibat dalam urusan kenegaraan, agama sebagai simbol tercermin dalam lembaga Negara. Sebagaimana semangat pan-islamisme yang dibawa oleh Jamaluddin al-Afghani dan sayid Rasyid Ridha.

${ }^{7}$ Pola taubid dalam Islam telah dianggap baku sebagai dasar perilaku Muslim. Untuk selanjutnya lihat Abu al-'A'la-Maududi, khilafah dan kerajaan, alih bahasa Ali Ihsan Fauzi, (Bandung :Mizan, 1988), 43. juga Fazlurrahman, tema-tema pokok al-Qur'an, alih bahasa Ahsin Muhammad, (Bandung: Penerbit Pustaka, 1985), 83. 
Islam sebagai agama yang Rahmatan Lil 'Alamin. Hal demikian menunjukkan bahwa dalam Islam, doktrin agama merupakan bagian integral yang mendasari tingkah laku manusia. Sebagai mana kehidupan Nabi SAW. Pada awal sejarah lahirnya Islam telah banyak fakta-fakta dan bahkan konsensus- konsessus politik. Sistem pemerintahan pada masa Nabi dan dua Khalifahnya disebut oleh Thaha Husein sebagai sistem pemerintahan yang bercorak Arab murni yang batasan-batasannya ditentukan oleh agama, boleh jadi juga turut menumbuhkan pemahaman bahwa pemerintahan Nabi dan kedua Khalifahnya sebagai pemerintahan yang Ilahiah dan sakral. Menurut Thaha, Al-Qur'an tidak mengatur sistem pemerintahan secara umum maupun khusus. Dengan demikian pemerintahan Nabi dan Khalifah di Madinah bukan pemerintahan yang didasarkan kepada wahyu, melainkan insan, dalam arti dibangun sesuai dengan kepentingan temporal, sehingga tidak pantas jika dipandang sakral.

Dimana selain beliau memiliki otoritas spiritual yang mutlakdari Allah SWT dalam bentuk kenabian, beliau juga mempunyai otoritas sosial-politik sebagai pemimpin Negara. Prinsip demokrasi yang beliau tampilkan pada periode ini hadir dengan terbentuknya piagam Madinah yang sangat mengedepankan nilai keadilan dan kesamaan hak serta kedudukan di depan hukum. Setelah Nabi wafat sistem kepemimpinan demokratis tersebut berlanjut ke masa pemerintahan Khulafaur-Rasyidin, dan baru mengalami distorsi menjadi sistem dinasti (Malkiyyat/kerajaan) pada periode berikutnya.

Sistem dinasti ini berlangsung selama beberapa periode, yaitu pada masa pemerintahan dinasti Umaiyyah dan Abbasiyah yang menerapkan sistem monarki dalam kelanjutan sebuah kepemimpinan. Meskipun periode ini merupakan akhir dari demokrasi klasik, suatu hal yang tidak dapat dipungkiri bahwa pada masa pemerintahan inilah Islam memiliki suatu periode yang dapat menstabilkan kehidupan politik dan intelektual yang paling cemerlang.

Pada perkembangan selanjutnya, beberapa aktor pembaharu dalam dunia politik Islam banyak bermunculan guna menawarkan sistem pemerintahan yang releven. Seperti Jamaludinal-Afgani, Muhamad Abduh, Rasyid Rida, Ali Abdul Raziq dan pembaharu lainnya dari berbagai penjuru dunia. Salah satu yang banyak 
ditemukan dari rasionalisasi sejarah masyarakat itu adalah karya al-Mawardi yang berjudul al-Ahkamal-Sultaniyyah ${ }^{8}$. Dibawah berbagai kecurigaan pemikir modern, karya ini muncul bukan saja berbagai gambaran sosial-budaya tetapi sebagai karya acuan dan standar politik Muslim. ${ }^{9}$

Sejalan dengan karya tersebut telah muncul karya lain yang hampir mengimplikasikan sama atas persoalan-persoalan yang dibangun al-Mawardi kalaulah mungkin justru memperkuat dan melengkapinya dengan unsur-unsur senti mengkelompok dan mungkin dengan nuansa mistis ke daerahan. ${ }^{10}$ Agama dan Negara dapat diasumsikan telah terpisah secara teoritis walaupun suasana konflik antar berbagai sekte keagamaan dalam Islam.

Diantara pandangan pembaru atau pemikir Islam tentang sistem pemerintahan Islam adalah: Pertama, memandang bahwa khalifah tradisional tidak bersifat mandat dan tidak secara ketat berdasarkan syari'ah. Dengan demikian umat Islam bebas memilih mengambil bentuk pemerintahan yang dianggap ideal. Kedua, bahwa Islam tidak menentukan norma-norma politik apapun, sehingga umat Islam bebas memilih cara yang bisa diterima untuk menangani masalah keduniawian mereka.

Bersamaan dengan kontroversi mengenai sistem pemerintahan yang ideal tersebut, disisi lain muncul gerakan Islam modern di bawah bendera Ikhwanul Muslim yang didirikan oleh Hassan al-Banna. Menurutnya pembaharuan harus dimulai dengan perjuangan kemerdekaan dari kolonoalisme, dengan membangun Negara dan system pemerintahan yang kuat berdasarkan prinsip Islam, serta memperjuangkan kemakmuran dan keadilan sosial berdasarkan Syari’ah.

Betapapun telah terjadi dinamika khilafiah dalam konteks tersebut, namun satu tawaran yang pasti tentunya bahwa prinsip dan sistem Negara yang ideal adalah system yang didasarkan pada semangat kemanusiaan sebagaimana prinsip dasar Syari'ah Islam. Langkah ini walaupun tidak diketahui seketika namun

\footnotetext{
${ }^{8}$ LihatAbuHasanibnMuhammad al-Mawardial-Basri,al-Ahkamal-Sultaniyyah,(Beirut:DaralFikr,t.t.)

${ }^{9}$ W.Montgomery Watt,Islamik politicalThought,(EdinburghuniversityPres,1968). Hlm.101

${ }^{10}$ Untuk melihat suasasa mistis Persian Ibn Taimiyyah mendefenisikanSultansebagaibayanganTuhandibumi(zilluAllabfial-ard) Selanjutnya lihat Taqiyuddin Ibn Taqiyuddin al-Siyasah al-Syar'iyyah,(kairo:Daral:Fike,t.t), hlm.208
} 
secara berangsur-angsur akan dapat dipahami dan diterima oleh kalangan umat Islam. Maka yang harus ditegaskan kembali adalah bahwa kesatuan prinsip dan sistem politik dalam Islam lebih diasumsikan dalam pengertian untuk berbeda sebagaimana yang didefinisikan orang Barat.

Dalam pranata praktis memang bentuk dan sistem pemerintahan dalam Islam sesungguhnya tidak harus berlambangkan Islam, namun secara substansi berasaskan Islam, sebagaimana yang terdapat pada banyak Negara dewasa ini. Dan landasan yang sangat subtansial dipakai dalam pengertian ini akan merujuk pada sistem nilai. Bagi pendalaman materi ini maka ide sekularisme menjadi tidak relevan, karenanya yang menjadi relevan menurut Nurcholis Madjid adalah sekularisasi. Perhitungan ini tentunya lebih ditekankan oleh peran pemikiran dan terlembagakan dalam konsep ijtihad.

Sejarah politik Islam di Indonesia yang dimulai sejak zaman penjajahan kolonial Belanda.Setelah kolonial Belanda menyerah tanpa syarat kepada Jepang, dengan demikian jepang mempunyai pengaruh terhadap nasib bangsa Indonesia termasuk nasib politik Islam. Lintasan sejarah perkembangan dan pemikiran politik Islam di Indonesia diwarnai dengan sejarah partai Masyumi. Setelah partai Masyumi turut andil dalam perkembangan dan pemikiran politik Islam di Indonesia, setelah memasuki pentas kemerdekaan maka yang menjadi problem pelik adalah persoalan ideologi apa yang akan menjadi dasar negara Indonesia.

Perdebatan yang sangat sengit mengenai dasar negara, maka lintasan sejarah perkembangan dan pemikiran politik Islam di Indonesia selanjutnya adalah fenomena politik Islam multi partai dan munculnya wacana darul Islam atau negara Islam.Yang dimaksud multi partai adalah munculnya partai-partai Islam baru di luar partai Masyumi yang pada akhirnya dalam pentas politik juga menjadi pesaing partai Masyumi termasuk Partai NU.

Untuk menyajikan periodesasi sejarah perkembangan dan pemikiran politik Islam di Indonesia, Islam Cendekia membagi periode perkembangan politik Islam ke dalam lima periode, yaitu ${ }^{11}: 1$. Politik Islam Masa Kolonial

${ }^{11} \mathrm{http}: / /$ www.islamcendekia.com/2014/01/sejarah-perkembangan-dan-pemikiran-politikislam-di-indonesia.html 
Belanda. 2. Politik Islam Masa Pendudukan Jepang. 3. Politik Islam Masa Pra Kemerdekaan dan Fenomena Masyumi. 4. Politik Islam Masa Kemerdekaan dan Perdebatan Dasar Negara. 5. Politik Islam Masa Multi Partai dan Fenomena Darul Islam.

Paska runtuhnya rezim orde baru atau rezim Soeharto dengan datangnya era reformasi kemudian mulai menjamurnya partai-partai Islam seperti Partai Amanat Nasional (PAN) pimpinan Amin Rais, Partai Kebangkitan Bangsa (PKB) pimpinan Gus Dur, Partai Bulan Bintang (PBB) pimpinan Yusril Ihza mahendra, PKNU, dan lain-lain.

\section{Macam Politik}

Politik Islam secara umum terbagi menjadi tiga macam:

\section{Siyasah Dusturiah}

Siasah Dusturiah merupakan segala bentuk teori-teori tentang politik tata Negara dalam Islam termasuk masalah perundang-undangan Negara harus sejalan dengan nilai-nilai Syari'at secara konstitusional tercermin dalam prinsip-prinsip Islam yang ada al-Qur'an dan sunah Nabi, baik mengenai akidah, ibadah, akhlak, muamalah, maupun berbagai macam hubungan yang lain.

Pada prinsipnya undang-udang dasar adalah jaminan atas hak asasi manusia setiap anggota masyarakat dan persamaan kedudukan semua orang di mata hukum tanpa membeda-bedakan status sosial, kekayaan, pendidikan, dan agama sehingga tujuan dibuatnya peraturan perundangundangan adalah kemaslahatan manusia dan untuk memenuhi kebutuhan manusia.

\section{Siyasah Dauliyah}

Siyasah dauliah merupakan segala bentuk tata ukuran atau teori-teori tentang system hukum internasional dan hubungan antar bangsa. Pada awalnya Islam hanya memperkenalkan satu system kekuasaan dibawah risalah Nabi Muhammad SAW dan berkembang menjadi system khilafah 
atau kekhilafahan. Dalam sistem ini dunia internasional, dipisah dalam tiga kelompok kenegaraan, yaitu;

a. Darussalam, yaitu Negara yang ditegakkan atas dasar syariat Islam dalam kehidupan.b.Darul-Harbi, yaitu Negara non Islam yang kehadirannya mengancam kekuasaan Negara-negara Islam serta menganggap musuh terhadap warga negaranya yang menganut Islam.

c. Darul-sulh, yaitu Negara non Islam yang menjalin persahabatan dengan Negara-negara Islam, yang eksistensinya melindungi warga Negara yang menganut agama Islam.

Antara Darussalam dan Darul Sulh terdapat persepsi yang sama tentang batas kedaulatannya, untuk saling menghormati dan bahkan menjalin kerja sama dengan dunia internasional. Keduanya saling terkait oleh konveksi untuk saling menyerang dan hidup bertetangga secara damai, sementara hubungan antara darus-salam dengan darul-harb selalu diwarnai sejarah hitam. Masing-masing selalu memperhitungkan terjadi konflik, namun demikian Islam telah meletakkan dasar untuk tidak berada dalam posisi pemrakarsa meletusnya perang. Perang dalam hal ini merupakan letak mempertahankan diri atau sebagai tindakan balasan.

Perang dalam rangka memperingati serangan musuh di dalam Islam memperoleh pengakuan yang sah secara hukum, dan termasuk dalam kategori jihad. Jihad dalam bentuk perang didalam mempertahankan diri atau tindakan balasan. Dalam arti terbatas di dalam rangka menaklukan lawan bukan untuk membinasakan dalam arti pembantaian atau pemusnahan. Oleh karena itu, mereka yang menyerah, tertawan, para wanita, orang tua, dan anak-anak, orang-orang cacat, tempat-tempat ibadah dan sarana serta prasarana ekologi rakyat secara umum harus dilindungi.

3. Siyasah Maaliyah

Siyasah maaliyah merupakan politik yang mengatur sistem ekonomi dalam Islam. Politik ekonomi Islam yang menjamin terpenuhinya kebutuhan primer setiap rakyat dan tercukupinya kebutuhan pelengkap 
sesuai kadar kemampuanya. Untuk itu, semua kebijakan ekonomi Islam harus diarahkan untuk menjamin terpenuhinya kebutuhan asasi dan terpenuhinya kebutuhan pelengkap pada setiap orang yang hidup dalam Negara Islam, sesuai dengan syariat Islam. Karena income Negara untuk terealisasinya pemenuhan kebutuhan ekonomi Negara melalui zakat, kharraj, jizyah, dan denda serta segala bentuk incame yang sesuai dengan syari'at Islam. ${ }^{12}$

\section{Politik Islam Kontemporer}

Pemikiran Politik Islam kontemporer mulai tampak ketika dunia Islam dalamkeadaan terjajah oleh kekuatan barat.Paratokoh pembaharu Islam seperti Jamaludin al-Afghani untuk mengumandangkan produksi pemikiran dalam mensikapi dan menggalang umat Islam dalam menghadapi.

Keabsahan teori politik Islam kontemporer tentunya tidak bisa terlepas dari ideologis Barat. Begitu juga dengan demokrasi, perlindungan Hak Asasi Manusia (HAM) dan konstitusionalisme, juga tidak terlepas dari intervensi Barat masuk dalam dunia Islam. Dengan perkembangan paham kebangsaan yang kemudian mengilhami terbentuknya Negara-Negara Bangsa yang modern dan sekuler. Keadaan ini kemudian memancing timbulnya berbagai konflik jika diantara penguasa dan warga Negara atau kekuasaan dan kebangsaan yang kemudian muncul sebagai infrastruktur kebebasan yang tak dapat dielakkan. ${ }^{13}$

Ketika kekuasaan raja-raja meram bahke suatu Negeri beserta seluruh rakyatnya yang hanya berkuasa atas teritori tententu dan dalam urusan-urusan duniawi saja mulai terjadi persoalan tentang dan dalam urusan-urusan raja. Yang dipertanyakan adalah darimana raja memiliki kekuasaan atas teritori dan urusan keduniawian. Persoalan itu tidak muncul ketika teori ketuhanan dan wacana kedaulatan masih berlaku bagi penguasa Negara-negara atau raja-raja.

Sebab dengan teori ketuhanan, raja yang berkuasa dianggap memiliki legitimasi sebagai wakil Tuhan atau pelaksana kekuasaan Tuhan yang harus

${ }^{12}$ http:// fikriyudin.blogspo t.co.id/2014/05/politik-dalam-perspektif-al-quran.html

13 Lihat Moh.Mahfudh MD,"Politik Hukum: Perbedaan Konsepsi Antara Hukum Barat dan Hukum Islam, al-Jami’ah, No, 63, Vol, VI, 1999, 29. 
dipatuhi seperti halnya Paus digereja. Namun setelah raja-raja dan kaisar itu tidak lagi berkuasa atas urusan-urusan rohani umatyang universal dan melintasi garis teritori dan kebangsaan maka mulai timbul pertanyaan tentang dasar legitimasi bagi seorang raja atau kaisar.

Kekuasaan raja-raja ditimbulkan oleh konflik yuris diksiantara Negaranegara dangereja (Paus) yang berkuasa pada abad-abad ke-13 dan14. Pada satu pihak raja dengan lambang kekuatan nasionalnya melakukan ekspansi untuk melebarkan kekuasaannya atas wilayah-wilayah lain beserta penduduknya yang sebangsa. Sedangkan Paus berusaha menegakkan kekuasaan politik gerejanya tanpa membedakan kebangsaan dan wilayah yang didiaminya. Benih skularisasi itu sendiri telah dimulai dari pertanyaan Paus Gregoris VII yang pada tahun 1075.

Raja-raja atau kaisar mengusai pemerintahan suatu teritori tertentu dalam masalah duniawi walaupun demikian raja tetap di bawah paus dan pendeta.Hal ini kemudian menimbulkan persoalan tentang legitimasi kekuasan raja dalam masalah diniawi. Jika semula kekuasaan itu tidak ada lagi, karena urusan perintah Tuhan atau pembinaan rohani masyarakat dilakukan oleh Paus dan para pendeta atau gereja-gereja kekuasaan itu kini menjadi sekuler. ${ }^{14}$

Dikatakan bahwa raja berkuasa bukan karena anugrah Tuhan melainkan karena manusia yang membuat kesepakatan atau perjanjian masyarakat (social contract). Didalam rasionalisasi ini disebutkan bahwa raja berkuasa karena ada perjanjian masyarakat yang memberi kekuasaan duniawi kepada raja untuk mengatur perbedaan kepentingan yang kerap kaliber benturan ketika manusia masih dalam status naturalis. Dengan teori ini tadinya penduduk yang dikuasai secara mutlak oleh raja menjadi berani menyatakan statusnya sebagai warga negara yang melalui suatu kontraksosial yang konstitusional dan legal memberia manat kepada mereka yang dipercaya dapat menata dan mengolah kehidupan para warga Negara itu.

Dengan rasionalisasiini kekuasaan raja dan pemerintah itu adalah rakyat dengan kedaulatannya.Teori kedaulatan rakyat yang kemudian disamakan dengan

${ }^{14}$ Lihat Moh. Mahfudh MD.,"Politik Hukum:perbedaan konsepsi antarabukumBaratdanHukumIslam,alJami'ah,..., 31 . 
konsep demokrasi dengan dasar teori Suara rakyat suara Tuhan (voxpopuli, voxdei). ${ }^{15}$ Dalam perkembangannya teori kedaulatan tersebut dalam praktiknya mengalami berbagai para dokseksistensi. Abual-'A'laal-Maududi, ${ }^{16}$ sebagai salah seorang intelektual Muslim yang berusaha menguraikan ajaran Barat tentang kedaulatan rakyat.

Sudut pandang theologis, al-Maududi hendak mereka mulang pemikiranpemikiran politik Muslim sebelumnya menyebutkan adanya keterkaitan antara agama dan Negara dalam kerangka syar'i. Asumsial-Maududi berpijak pada asas Islam yaitu Tauhid. Segala perilaku sosial-politik harus didasarkan pada asas ini, maka tidaka da hukum kecuali hukum Allah.

Al-Maududi sangat memahami praktek yang memberlakukan hukum besi oligarki (the ironlawofoligarchy), yaitu sekelompok penguasa saling bekerja sama untuk menentukan berbagai kebijakan politik, sosial dan ekonomi tanpa harus menanyakan bagaimana sesungguhnya aspirasi rakyat yang sebenarnya. Disamping itu al-Maududi juga memahami bahwa suara mayoritas yang biasanya menentukan sistem demokrasi sebagai teori kedaulatan rakyat (people sovereignty).

Pemerintahan Islam bukan untuk dikuasai oleh kaum agamawan tertentu atau kaum ulama', namun dikuasai oleh seluruh masyarakat Muslim itu sendiri. Dan bahwa Islam memberikan kedaulatan terbatas pada rakyat telah jelas diatur dalam teori politik Islam sebagai bahan penyeimbang stabilitas politik. Namun demikian Islam menegaskan bahwa pemerintah tidak boleh menggunakan kedaulatan rakyat itu dengan semaunya, karena ada norma-norma dan nilai-nilai Ilahi yang harus menjadi rujukan politik dan ekonomi yang ditentukan oleh rakyat melalui para wakilnya.

Dalam tataran ini al-Maududi kemudian menciptakan istilah theodemocracy dalam teori politiknya. Dengan kata lain,kedaulatan rakyat terbatas di bawah pengawasan Tuhan. Interaksi agama dalam pengertian yang sangat luas,

\footnotetext{
${ }^{15}$ Lihat Moh. Mahfudh MD .,'Politik Hukum: Perbedaan Konsepsi antara hukum Barat dan hokum Islam, al-Jami'ah ,No, 63, Vol, VI, 1999, hlm, 32.

${ }^{16}$ Untuk diskusi tentangteori politik Maududi,lihatnya dalam karyanya khilafah dan kerajaan,alih bahasa Ali Ihsan Fauzi.(Bandung: Mizan,1988).
} 
maka akan ditemukan aturan-aturan terbatas pada pengertian agama yang dipahami sebagai ajaran Muhammad SAWyang hanya terkait dengan urusanurusan ibadah semata. Dengan demikian, maka sekat-sekat tersebut sangat jelas membatasi Universalitas Islam itu sendiri. Dalam pengertian apapun agama hanya akan menjadi sumber keresahan karena telah menciptakan diskriminasi kelas maupun imagi. Bila hal itu dirangkai menjadi konsep yang permanen maka agama justru meniadakan makna peradaban itu sendiri. Dan agama menjadi tragedy bagi pengikutnya sendiri. Dan hal tersebut merupakan paradok yang harus dihapuskan dari imagi manusia yang paling dalam.

Gerakan Islam Politik menyebut bahwa berpolitik dengan basis ideologi agama akan sangat mempengaruhi kebijakan, tentu didalamnya kebijakan negara. Sebab politik akan semakna dengan siasat (siasah) dan seni dalam mengatur Negara. Relasi, baik dalam konteks individu dengan individu, satu social group dengan social group lain, bangsa satu dengan bangsa lain, dapat disebut sebagai kegiatan politik. Jadi menurut kelompok ini, bagaimana pola relasi semacam itu, harus dilakukan tanpa menggunakan piranti ideologi keagamaan.

Menurut Ali Abdul Raziq Agama Islam terbebas dari khilafah yang dikenal kaum Muslim selama ini, dan juga terbebas dari apa yang mereka bangun dalam bentuk kejayaan dan kekuatan. Khilafah bukanlah bagian dari rencana atau takdir agama tentang urusan kenegaraan. Tapi ia semata-mata hanyalah rancangan politik murni yang tak ada urusan sama sekali dengan agama. Agama tidak pernah mengenalnya, menolaknya, memerintahkannya, ataupun melarangnya.

Menurut Khallaf kekuasaan negara dapat didelegasikan kepada, kekuasaan membuat undang-undang (al-sulthat at-tasyri"iyat), kekuasaan peradilan atau kekuasaan kehakiman (al-sulthat al-qadhaiyat), dan kekuasaan melaksanakan undang-undang (al-sulthat al-tanfiziyat) dapat disebut juga kekuasaan legislatif, eksekutif dan yudikatif. 


\section{Kesimpulan}

Perkembangan politik Islam dilihat dari dinamisnya Islam itu sendiri.politik Islam itu berkembang dan menimbulkan kontroversi, Misalnya berkaitan dengan sistem pemerintahan yang digunakan oleh pemimpin-pemimpin Islam. Rasulullah sendiri memimpin umat Islam yang berada di makkah dan madinah bersumber dari al-Qur'an walaupun di dalam al-Qur'an sendiri tidak termaktub sistem negara atau sistem pemerintahan. Akan tetapi gejolak perpolitikan itu mulai pada masa khalifah ar-Rasyidin sampai khalifah-khalifah yang menggunakan politik dinasti bani seperti bani umaiyah, bani abbasiyah dan lain-lain.

Sejak kekhalifahankhalifah ar-rasyidin terutama kekhalifahan Usman dan Ali sudah mulai benih-benih pertikaian politik dalam Islam itu muncul dan berkembang. Sampai pada kekhalifahan berbentuk kerajaan bukan lagi ditunjuk oleh perwakilan umat islam sebagaimana pemilihan khalifah ar-rasyidin. Politik dalam arti siyasah dengan demikian para pemikir membagi politik Islam menjadi dua diantaranya pertama SiyasabDusturiyah dan yang kedua siyasah dauliyah.

Selanjutnya politik Islam muncul istilah sekuleralisme yang ingin memisahkan antara negara dan agama sebagaimana sistem politik dan pemerintah di dunia barat. Ada negara mayoritas Islam yang menganut sistem negaranya menjadi negara sekuler adalah Turki, begitu juga dengan negara-negara barat atau negara non muslim menganut negara sekuler. Akan tetapi menurut kebanyakan pemikir-pemikir islam kontemporer menyebutkan bahwa negara tidak bisa dipisahkan dari agama ibarat mata uang.

Di Indonesia salah satu negara yang tidak menganut sistem negara sekuler dan tidak negara agama akan tetapi negara hukum. Walaupun demikian partai-partai Islam dan partai nasionalis berkembang dengan perjuangan yang sama yaitu ingin menjadikan negara indonesia menjadi negara yang maju. Partai-partai politik yang ada ingin menjadikan negara maju berasaskan pancasila, tidak ingin menjadikan negara agama dan negara sekuler. 


\section{Daftar Pustaka}

Abu Zahra, Muhammad,Tarikh al-mazahib al-Islamiyah, Beriut:Dar al- fikr, t.t.

Azra, Azyumardi, siyasah, syari'ah, dan historiografi, Dalam Muhammad wahyudi Nafis (ed),kontekstualisasi Ajaran Islam, Jakarta IPHI dan paramadina, 1995

Esposito, john L. dan John O. Voll, Demokrdiasi dan Negara-negaraMuslim, Bandung: Mizan, 1995

Fauzan, Islam dan Kemodernan Politik berbasis Pemuda, (Tangerang: Binamuda, 2008),

Gaffar, afan, Islam dan Demokrasi, dalam Muhammad WahyuniNafis (ed), Kontekstualisasi Ajaran Islam, Jakarta IPHI dan Paramadina, 1995

Maududi, Abu Al-'A'la, khilafah dan Kerajaan, Alih bahasa Ahsin

Muhamad, Bandung: Mizan, 1986

Mawardi, Abu hasan Ibn Muhammad, al-ahkam al-sultaniyyah, Beirut, Dar Alfikr,t.t.

Mahfudz, Muhammad MD., "Politik Hukum Perbedaan Konsepsi antara Hukum Barat dan Hukum Islam, al-jami'ah, No 63. Vol. VI, 1999.

Mahfudh, MA. Sahal, Nuansa FIQIH SOSIAL, LKiS, cet I 1994, Yogyakarta. Hal : Taqiyuddin Ibn Taqiyuddin al-Siyasah al- Syar'iyyah,(kairo:Dar al:Fike,t.t),

Ibn taimiyyah, taqiyuddin, al-siyasah, Kairo. Dar al-kutub, t.t.

Raziq, Ali abd., khilafah dan pemerintahan dalam Islam, alih bahasaAhsin Muhammad, Bandung: penerbit pustaka, 1985

Rahman, Fazlur, Islam, alih bahasa Ahsin Muhammad, Bandung:penerbit pustaka, 1986

Sadat, Anwar, "West and East, Shall They Meet, dalam Kemal H. karpat, politicalnand social Thought in the contemporary Middle East, New York: CBS, 1982

Schacht, joseph, Intruduction to Islamic Law, Boston: Clerendon Press, 1967

Shihab, M. Quraish, Wawasan Al-Quran, (Mizan: Bandung, 1996) 
Watt,W.Montgomery,Islamic Political Thought, Edinburgh: EdinbrughUniv ersity Press, 1968

http://www.islamcendekia.com/2014/01/sejarah-perkembangan-dan-pemikiranpolitik-islam-di-indonesia.html http://fikriyudin.blogspot.co.id/2014/05/politik-dalam-perspektif-al-quran.html 